\title{
K-MEANS SEBAGAI EKSTRAKTOR CIRI PADA KLASIFIKASI DATA DENGAN ALGORITMA SUPPORT VECTOR MACHINE (SVM)
}

\author{
Nurul Chamidah \\ Fakultas Ilmu Komputer, Program Studi Informatika \\ Universitas Pembangunan Nasional Veteran Jakarta \\ Email: nurul.chamidah@upnvj.ac.id
}

\begin{abstract}
ABSTRAK
Besarnya dimensi pada ciri merupakan masalah pada komputasi untuk mengklasifikasi data sehingga diperlukan suatu proses ekstraksi ciri agar dimensinya berkurang dengan cara mengambil hanya informasi yang penting dari ciri. Penelitian ini menggunakan algoritma K-Means untuk mengekstraksi ciri dengan menemukan pola tersembunyi dari setiap kelas kemudian direkonstruksi dengan fuzzy membership function dan mendapatkan pola baru. Pola baru yang terbentuk digunakan sebagai ciri abstrak dan dibagi kedalam data latih dan data uji. Pelatihan dilakukan dengan memanfaatkan algoritma Support Vector Machine (SVM) untuk mendapatkan model klasifikasi. Model klasifikasi SVM yang diperoleh kemudian di uji dengan menggunakan data uji untuk memperoleh performa klasifikasi berupa akurasi dan waktu komputasi. Dengan 5-fold cross validation, metode ini memberikan akurasi yang baik pada Dataset Liver, Breast Cancer dan Heart Disease yang diperoleh dari UCI Machine Learning Repository. Penelitian ini menunjukkan kemampuan K-Means untuk mengekstraksi ciri dari dataset. Hasil penelitian ini menujukkan bahwa K-Means sebagai ekstraktor ciri dapat mengurangi waktu komputasi.
\end{abstract}

Kata kunci: ekstraksi; ciri; klasifikasi; k-means; SVM, akurasi.

\section{ABSTRACT}

The high dimension of feature data is one of the problem for computation to classify data, it causing the need for feature extraction to reduce its dimension by retrieving only important information form the features.This research using $K$-Means Algorithm to extract features and finding hidden pattern form each class then reconstructed by fuzzy membership function and get new pattern. New pattern that obtained is used as abstract features and divided into training data and testing data. Training is done by Support Vector Machine (SVM) algorithm to obtain classification model. SVM classification model is tested using testing data to get classification performance as accuracy and computational time. Based on 5-fold cross validation, this method has a good accuracy using Liver Dataset, Breast Cancer Dataset, and Heart Disease Dataset from UCI Machine Learning Repository. This research shows the ability and capability of $K$-Means for extracting features in dataset. The result of this research shows that using $K$-Means as feature extractor can reduce computational time.

Keywords: extraction; feature; classification; $k$-means; SVM; accuracy.

\section{PENDAHULUAN}

Perkembangan teknologi yang semakin canggih memudahkan manusia mengambil berbagai ciri yang diinginkan pada berbagai masalah dan kasus, menyebabkan pertumbuhan data yang sangat pesat diberbagai bidang. Peningkatan dimensi ciri pada data menyebabkan berbagai analisis data dan klasifikasi menjadi lebih sulit dilakukan karena semakin besar dimensi semakin besar waktu komputasi dan memory yang diperlukan untuk analisis [1].

Fenomena Hughes menyebutkan bahwa peningkatan dimensi ciri tidak menjamin akurasi dari pengenalan [2]. Dari fenomena ini, penelitian-penelitian telah dilakukan untuk mereduksi jumlah ciri seperti dengan pemilihan ciri (feature subset selection) dengan perankingan pada paralinguistic analysis [3], pada penelitian citra kerusakan mentimum menggunakan Max-Relevance Min-Redundancy (MRMR), Mutual Information Feature Selection (MIFS), dan Sequential Forward Selection (SFS) [4]. Penelitian lainnya mereduksi jumlah ciri dengan melakukan pengurangan dimensi ciri (dimensionality reduction) dengan neural fuzzy pada data medis [5], Principal Component Analysis (PCA) pada data email dan obat[1].

Selain dengan mereduksi jumlah ciri, beberapa peneliti menerapkan ekstraksi dan seleksi ciri sekaligus [6], [7], yakni ciri yang diekstrak dan dipilih merupakan ciri yang baik sehingga akurasi tidak menurun, dan karena telah diekstrak dan dipilih, maka performa klasifikasinya juga menjadi cepat. Ekstraksi dan seleksi ciri dengan KMeans sebagai telah dilakukan [8] untuk mengekstrak data breast cancer dan mengklasifikasikan ke dalam dua 
kelas dengan SVM dari 32 ciri menjadi 6 ciri. Penelitian Chamidah dan Wasito [9] menerapkan klasifikasi decision tree dan SVM pada tiga kelas dengan data Cardiotocography dari 21 ciri menjadi 5. Hasil penelitian menunjukkan signifikansi hasil klasifikasi dan peningkatan performa.

Wolpert dan Mcready [10] menyebutkan, bahwa tidak ada model terbaik secara umum. Setiap kasus memiliki data yang unik dan memiliki penyelesaian yang unik. Oleh karena itu, pada penelitian ini akan diujicobakan klasifikasi dengan K-Means sebagai ekstraktor ciri dan SVM sebagai algoritma klasifikasinya menggunakan dataset medis Liver, Breast Cancer, dan Heart Disease untuk mengevaluasi performa ekstraksi dan seleksi ciri pada klasifikasi SVM.

\section{METODOLOGI PENELITIAN}

Metode penelitian yang digunakan dalam penelitian ini dapat dilihat pada Gambar 1. Penelitian dilakukan dengan (1) mengumpulkan data dan dilakukan suatu (2) praproses. Data yang telah dipraproses kemudian (3) diekstraksi dan seleksi ciri. Hasil ekstraksi dan seleksi kemudian (4) direkonstruksi untuk membentuk ciri abstrak yang merupakan ringkasan informasi yang penting dari ciri. Proses berikutnya, data yang berisi hasil rekonstruksi ciri (4) dibagi ke dalam data latih dan data uji. (5) Data latih digunakan untuk membangun model dengan menggunakan SVM dan (6) data uji untuk memvalidasi model SVM hasil latihan.

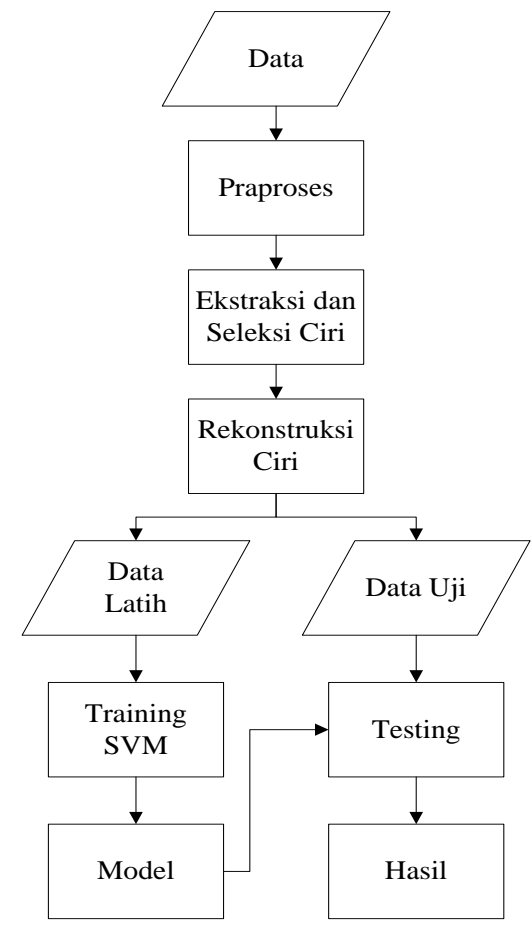

Gambar 1. Metode Penelitian

\subsection{Data}

Data diperoleh dari UCI Machine Learning Repository [11]. Data tersebut adalah data liver sebanyak 583 record yang terdiri dari klasifikasi liver sebanyak 167 record, dan nonliver sebanyak 416 record. Data breast cancer dengan total 569 record yang terdiri dari 357 record berupa kanker jinak dan 212 record kanker ganas. Data heart disease dengan total 303 record yang terdiri dari 160 data sehat dan 143 data sakit. Jumlah ciri dari masingmasing data yang digunakan dalam penelitian ini, untuk data liver sebanyak sepuluh ciri, data breast cancer sebanyak tiga puluh ciri, sedangkan data heart disease sebanyak tiga belas ciri.

\subsection{Praproses}

Praproses dilakukan dengan melakukan transformasi min-max ke dalam range 0-1 [12]. Dimana nilai baru nbaru diperoleh dengan membandingkan nilai lama nlama dikurangi nilai minimum nmi pada setiap ciri dengan nilai maksimum nmaks pada suatu ciri dikurangi dengan nilai minimumnya $n m i$ kemudian dikalikan dengan nilai maksimum baru maksbaru dikurangi minimum baru mibaru yang diinginkan dan dijumlahkan dengan nilai minimum baru yang diinginkan. Berikut formula normalisasi min-max, 
$n b a r u=\frac{n l a m a-n m i}{n m a k s-n m i}($ maksbaru - mibaru $)+$ mibaru

\subsection{Ekstraksi dan Seleksi Ciri}

Ekstraksi dan seleksi ciri ini dilakukan untuk mendapatkan pola tersembunyi dari tiap kelas secara terpisah dengan Algoritma K-Means. K-Means mengelompokkan ciri-ciri yang paling berpengaruh terhadap suatu kelas dengan mencari jarak terdekat antara pusat (centroid) dengan anggota cluster-nya.

$$
\min _{\overline{\mathrm{X}}_{1}, \mathrm{X}_{2}, \ldots \overline{\mathrm{X}}_{\mathrm{nK}}} \sum_{\mathrm{nk}=1}^{\mathrm{nK}} \sum_{\mathrm{i} \in \mathrm{H}_{\mathrm{nk}}}\left\|\mathrm{X}^{\mathrm{i}}-\overline{\mathrm{x}}_{\mathrm{nk}}\right\|^{2}
$$

Dimana $\mathrm{nK}$ adalah indeks cluster, $\mathrm{H}_{\mathrm{nk}}$ merupakan cluster set $\mathrm{ke}-\mathrm{nK}, \overline{\mathrm{x}}_{\mathrm{nk}}$ berupa pusat cluster atau centroid point dalam cluster $\mathrm{H}_{\mathrm{nk}}$.

K-Means secara iteratif menghitung jarak terdekat euclidean distance dengan mengadaptasi lokasi titik centroid. Jumlah cluster ditentukan dengan menghitung kriteria Calinski-Harabasz [13], [14]. Indeks CalinskiHarabasz didefinisikan sebagai [15]:

$$
\begin{aligned}
& \mathrm{CH}_{\mathrm{C}}=\frac{\mathrm{SS}_{\mathrm{B}}}{\mathrm{SS_{ \textrm {W } }} \times \frac{(\mathrm{N}-\mathrm{nK})}{(\mathrm{nK}-1)}} \\
& \mathrm{SS}_{\mathrm{B}}=\sum_{\mathrm{x}_{\mathrm{nk}} \in \mathrm{C}}\left|\mathrm{x}_{\mathrm{nk}}\right|\left\|\overline{\mathrm{x}}_{\mathrm{nk}}-\overline{\mathrm{X}}\right\|^{2} \\
& \mathrm{SS}_{\mathrm{W}}=\sum_{\mathrm{x}_{\mathrm{nk}} \in \mathrm{C}} \sum_{\mathrm{x}_{\mathrm{i}} \in \mathrm{x}_{\mathrm{nk}}}\left\|\mathrm{x}_{\mathrm{i}}-\overline{\mathrm{x}}_{\mathrm{nk}}\right\|^{2}
\end{aligned}
$$

Dimana $\mathrm{SS}_{\mathrm{W}}$ adalah jarak antara titik di dalam cluster ke centroid-nya (within cluster distance), $\mathrm{SS}_{\mathrm{B}}$ jarak antara centroid $\mathrm{ke}$ global centroid (between cluster distance), $\left|\mathrm{x}_{\mathrm{nk}}\right|$ jumlah anggota cluster ke- $\mathrm{nk}, \mathrm{x}_{\mathrm{nk}}$ cluster ke$\mathrm{nk}, \overline{\mathrm{x}}_{\mathrm{nk}}$ centroid cluster ke- $\mathrm{nk}, \overline{\mathrm{X}}$ rata-rata global dari dataset, $\mathrm{C}=\left\{\mathrm{x}_{1}, \mathrm{x}_{2}, \ldots, \mathrm{x}_{\mathrm{nK}},\right\}$ yakni clustering data $\mathrm{X}$ sebanyak $\mathrm{N}$ objek ke dalam nK grup dan jumlah grup $>1$.

Optimum cluster diperoleh dari nilai $\mathrm{CH}$ index yang maksimum. suatu hasil clustering dikatakan baik jika memiliki within cluster distance yang kecil dan between cluster distance yang besar Pencarian jumlah cluster yang optimal dari setiap dataset pada penelitian ini diuji pada jumlah cluster pada range cluster $\mathrm{nK}(2 \leq \mathrm{nK} \leq 10)$ untuk masing-masing kelas pada setiap dataset.

\subsection{Rekonstruksi Ciri}

Rekonstruksi filakukan setelah mendapatkan jumlah cluster optimum dan dilakukan clustering dengan KMeans sejumlah optimum cluster ini. Pola dari suatu kelas direpresentasikan oleh cluster-cluster yang membentuk kelas tersebut sebagai ciri simbolik yang disimbolkan dengan centroid cluster pada cluster tersebut. Ciri simbolik pada setiap kelas di dataset digunakan untuk menghitung similaritas antara data dengan ciri simboliknya. Proses ini berguna untuk mengetahui kecocokan data dengan pola baru yang telah ditemukan. Untuk menghitung similaritas ini digunakan fuzzy membership function [8] dari setiap data terhadap pola yang telah diidentifikasi (ciri pada centroid). Formulasi fuzzy membership function dapat dilihat pada rumus (6). Hasil dari fuzzy membership function kemudian digunakan untuk membentuk pola atau ciri simbolik yang dapat dilihat pada formula (7), yakni menghitung semua anggota kelas pada data terhadap fuzzy membership function, sehingga akan terbentuk ciri yang merupakan jumlah cluster dari seluruh kelas.

$$
\begin{aligned}
& \text { fuzzy }_{n p}\left(X_{j}^{i}\right)=\left\{\begin{array}{c}
1-\frac{\left|x_{j}^{\bar{x}_{n p}}-X_{j}^{i}\right|}{\max \left|X_{j}^{\bar{x}_{n p}}-X_{j}^{n}\right|} \text { if }\left(\min \left(X_{j}^{n}\right) \leq X_{j}^{i} \leq \max \left(X_{j}^{n}\right), \forall n \in H_{n p}\right. \\
0, \text { otherwise; }
\end{array}\right. \\
& \text { Pat }_{n p}=\frac{1}{D} \sum_{j=1}^{D} \text { fuzzy }_{n p}\left(X_{j}^{i}\right), 1 \leq n p \leq n K^{1}+n K^{2}
\end{aligned}
$$

Dimana np :indeks dari pola baru, $\mathrm{X}_{\mathrm{j}}^{\mathrm{i}}$ : ciri ke-j dari input asli $\mathrm{i}, \mathrm{X}_{\mathrm{j}} \overline{\mathrm{x}}_{\mathrm{np}}$ : ciri ke $\mathrm{j}$ dari centroid $\overline{\mathrm{x}}_{\mathrm{np}}$ untuk cluster $\mathrm{H}_{\mathrm{np}}, \mathrm{nK}^{1}$ : jumlah pola dari kelas $1, \mathrm{nK}^{2}$ : jumlah pola dari kelas 2. Pola yang diperoleh dari K-Means merupakan suatu ciri abstrak yang berbeda dari ciri sebelum di lakukan K-Means [8]. Dimensi ciri telah direduksi dengan ciri abstrak baru yang berisi kombinasi dari ciri-ciri sebelumnya dengan informasi ringkas. Kemudian ciri-ciri baru ini digunakan dalam pelatihan dengan SVM untuk memperoleh model klasifikasi yang selanjutnya akan digunakan untuk mengklasifikasi. 


\subsection{Data Latih dan Data Uji}

Data yang telah direkonstruksi dipisah menjadi data latih dan data uji. Data latih digunakan untuk membangun model klasifikasi SVM, dan data uji digunakan untuk menguji model yang telah dibangun. Pembagian data latih dan uji menggunakan 5-fold cross validation, yakni membagi data ke dalam lima bagian yang sama rata, kemudian secara bergantian mengambil empat bagian sebagai data latih dan satu bagian sebagai data uji. Pembagian data ini diilustrasikan pada

Gambar 2 dimana warna hitam menunjukkan data uji dan warna putih menunjukkan data yang digunakan untuk latihan.

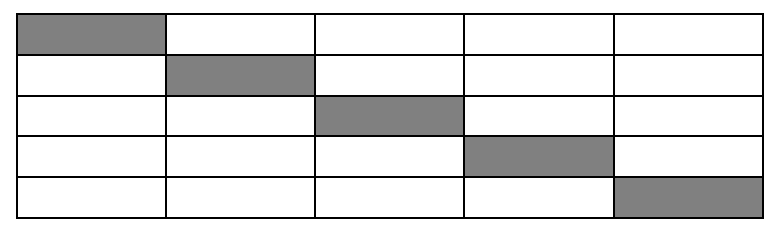

Gambar 2.5-Fold Cross Validation

\subsection{Klasifikasi dengan SVM}

Penelitian ini menggunakan algoritma SVM yang emanfaatkan hyperplane untuk pemodelan. Berikut formulasi dari SVM (Cortes dan Vapnik, 1995; Akay, 2009):

$$
\begin{aligned}
& \operatorname{maximize}_{\beta}\left[\sum_{\mathrm{i}=1}^{\mathrm{n}} \beta_{\mathrm{i}}-\frac{1}{2} \sum_{\mathrm{i}, \mathrm{j}=1}^{\mathrm{n}} \beta_{\mathrm{i}} \beta_{\mathrm{j}} \mathrm{y}_{\mathrm{i}} \mathrm{y}_{\mathrm{j}} \mathrm{K}\left(\mathrm{x}_{\mathrm{i}} \mathrm{x}_{\mathrm{j}}\right)\right] \\
& \text { subject to } \sum_{\mathrm{i}=1}^{\mathrm{n}} \beta_{\mathrm{i}} \mathrm{y}_{\mathrm{j}}=0,0 \leq \forall \beta_{\mathrm{i}} \leq \mathrm{L}
\end{aligned}
$$

Dengan $\mathrm{x}$ : training vector, $\mathrm{y}$ : label dari training vector, $\beta$ : vector parameter dari hyperplane classifier, $\mathrm{K}$ : Kernel function, menghitung jarak antara training vector $\mathrm{x}_{\mathrm{i}}$ dan $\mathrm{x}_{\mathrm{j}}, \mathrm{L}$ : parameter pinalti untuk mengontrol jumlah yang salah diklasifikasi, semakin besar $\mathrm{L}$, semakin akurat hasil klasifikasi.

\section{HASIL EKSPERIMEN}

Dari dataset liver, breast cancer, dan heart disease dilakukan pemisahan berdasarkan kelas pada setiap dataset-nya yang sebelumnya sudah dilakukan praproses. Data yang telah dipisah selanjutnya akan dievaluasi jumlah cluster yang optimum dengan menggunakan kriteria Calinski-Harabasz. Setiap kelas pada setiap dataset dikelompokkan dengan algoritma K-Means sejumlah optimum cluster yang telah diperoleh sebelumnya kemudian di rekonstruksi. Hasil rekonstruksi ciri ini digunakan dalam klasifikasi yakni pelatihan dan pengujian dengan algoritma SVM.

\subsection{Ekstraksi dan Rekonstruksi Ciri}

Pada dataset liver, record dibagi menjadi dua yakni kelas liver dan nonliver. Masing-masing data perkelas ini dikelompokkan dengan K-Means, jumlah cluster diperoleh dengan mengevaluasi Kriteria Calinski-Harabasz $(\mathrm{CH})$. Evaluasi jumlah cluster dengan kriteria ini dilakukan pada range cluster 2 hingga 10. Gambar 3 di bawah menunjukkan jumlah cluster yang optimum untuk tiap kelas liver dan nonliver pada dataset liver.

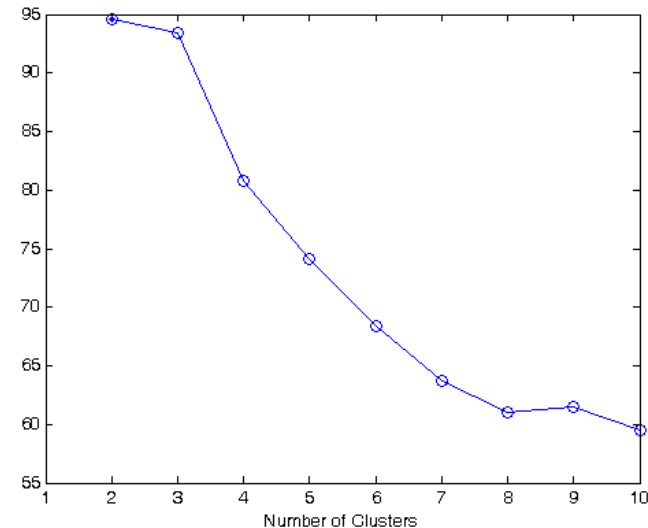

(a)

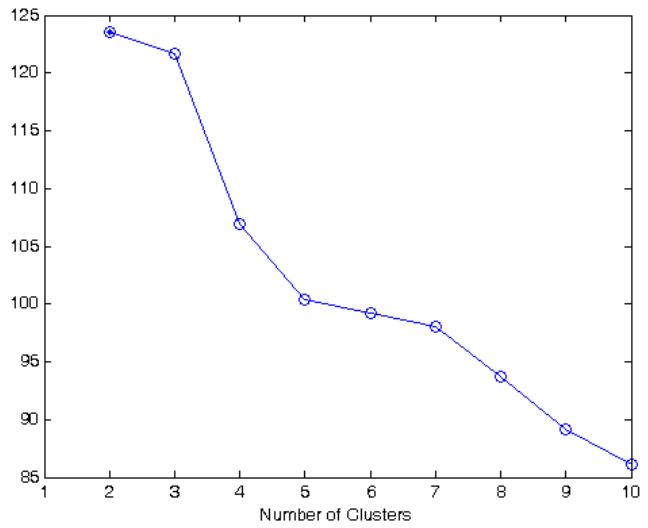

(b)

Gambar 3. Cluster Optimum pada Dataset Liver (a) Kelas Liver (b) Kelas Nonliver 
Kriteria Calinski Harabasz yang menunjukkan jumlah cluster yang optimum adalah kriteria dengan nilai tertinggi. Pada Gambar 3, data kelas liver dan nonliver dapat terpisah secara baik bila dikelompokkan ke dalam dua cluster yang ditunjukkan dengan nilai Calinski Harabasz maksimum. Pemisahan pada kelas liver ditunjukkan pada Gambar 3 (a) yang memvisualisasikan jumlah cluster optimum dengan dua cluster serta kelas nonliver terpisah dengan baik menurut kriteria Calinski Harabasz pada jumlah cluster sebanyak 2 yang ditunjukkan pada Gambar 3 (b), dimana puncak grafik berada pada number of cluster sejumlah 2.

Pada dataset breast cancer, record dibagi menjadi dua yakni kelas kanker jinak (benign) dan kanker ganas (malignant). Masing-masing data perkelas ini dikelompokkan dengan kmeans, jumlah cluster diperoleh dengan mengevaluasi Kriteria Calinski-Harabasz. Evaluasi jumlah cluster dengan criteria ini dilakukan pada range cluster 2 hingga 10. Gambar 4 di bawah menunjukkan jumlah cluster yang optimum untuk tiap kelas benign dan malignant pada dataset breast cancer.

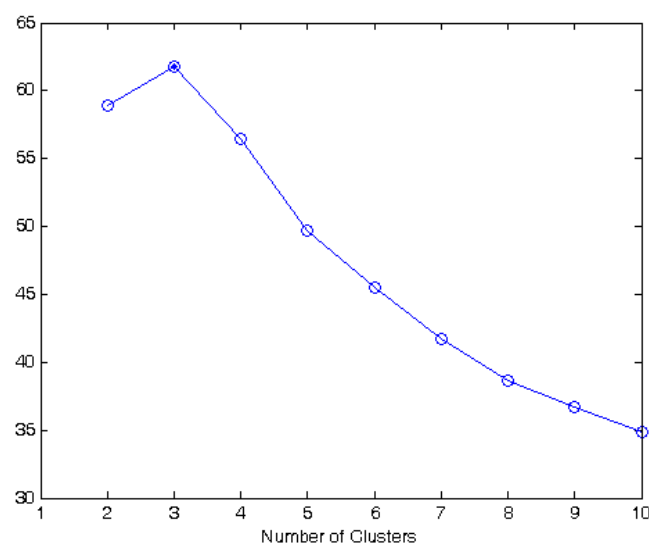

(a)

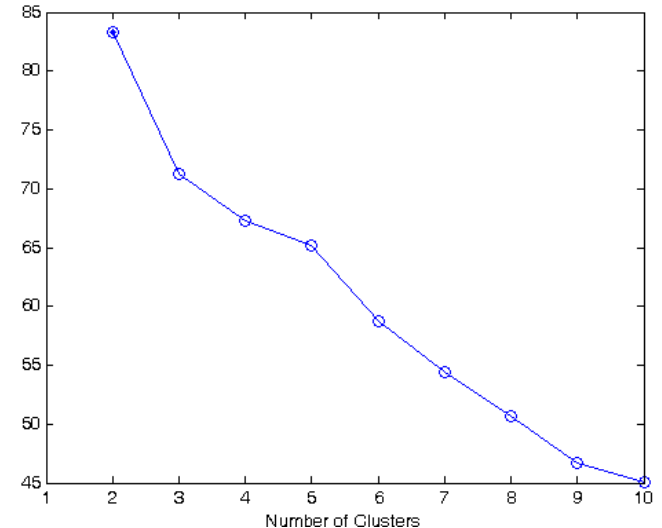

(b)

Gambar 4. Cluster Optimum pada Dataset Breast Cancer (a) Kelas Malignant (b) Kelas Benign

Gambar 4 menujukkan indeks Calinski Harabasz pada kelas malignant dan benign. Pemisahan pada kelas malignant ditunjukkan pada Gambar 4 (a) yang memvisualisasikan jumlah cluster optimum dengan indeks tertinggi pada pengelompokan ke dalam tiga cluster, serta kelas benign terpisah dengan baik menurut kriteria Calinski Harabasz pada jumlah cluster sebanyak dua yang ditunjukkan pada Gambar 4 (b), dimana puncak grafik berada pada number of cluster sejumlah dua.

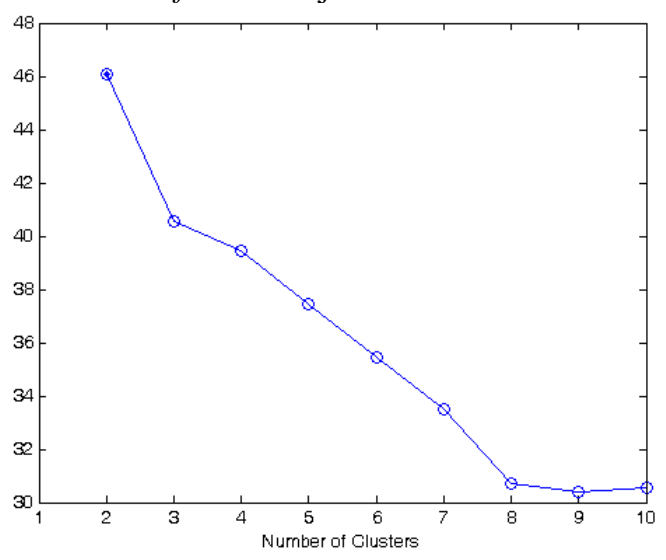

(a)

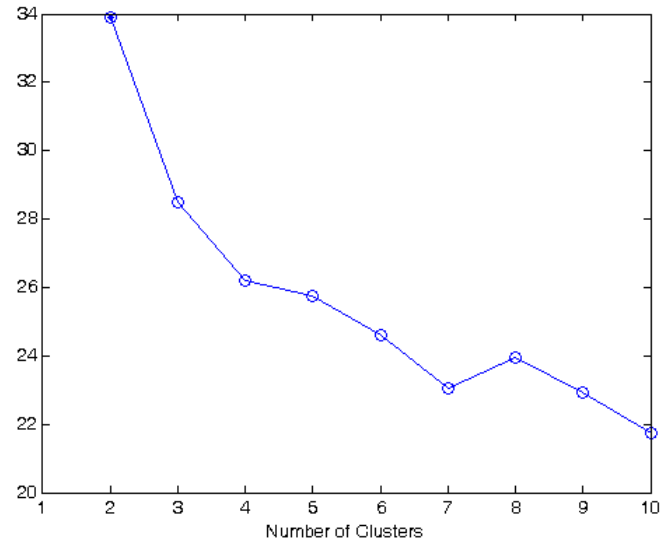

(b)

Gambar 5. Cluster Optimum pada Heart Disease Dataset (a) Kelas Sehat (b) Kelas Sakit

Gambar 5 menunjukkan evaluasi pemisahan cluster dari dataset penyakit heart disease yang dikelompokkan menjadi kelas sehat dan sakit. Berdasarkan evaluasi Calinski-Harabasz, kelas sehat optimum di kelompokkan ke dalam 2 cluster seperti yang ditunjukkan pada Gambar 5 (a), sedangkan kelas sakit optimum di kelompokkan ke dalam 2 cluster pula yang divisualisasikan pada Gambar 5 (b) sebagai nilai maksimum.

Setelah diperoleh jumlah cluster optimum untuk masing-masing kelas pada setiap dataset dan pengelompokan dengan K-Means sejumlah cluster optimum tersebut, dilakukan rekonstruksi ciri, yakni membentuk ciri baru berdasarkan hasil clustering dengan formula [6] dan [7]. Hasil perhitungan rekonstruksi ciri 
dengan fuzzy membership function dan pemnbentukan pola ini menghasilkan ciri baru berupa ciri abstrak dari setiap dataset dengan jumlah ciri yang telah tereduksi.

Rekonstruksi ciri ini memproses data liver dari sepuluh ciri menjadi empat ciri baru yang berasal dari hasil pengelompokan kelas liver dan nonliver masing-masing dua kelompok. Data breast cancer dari tiga puluh ciri menjadi lima ciri, serta data penyakit heart disease dari tiga belas ciri menjadi empat ciri baru. Dataset dengan ciriciri baru tersebut selanjutnya diproses pada fase latihan untuk menghasilkan classifier menggunakan algoritma SVM yang kemudian akan divalidasi dengan data uji.

\subsection{Klasifikasi dengan SVM}

Eksperimen dilakukan dengan 5-fold cross validation pada setiap dataset dan evaluasi performa dari metode ini dilakukan dengan menghitung akurasi pengujian serta waktu komputasi dari proses latihan, dimana akurasi merupakan persentase dari hasil klasifikasi yang diprediksi benar, dibandingkan dengan klasifikasi actual sebagaimana dapat dilihat pada formula 9.

$$
\text { akurasi }=\frac{\text { prediksi }}{\text { aktual }} \times 100 \%
$$

Pengujian dilakukan dengan melakukan pengulangan eksperimen sebanyak sepuluh kali dan mengambil ratarata performa setiap eksperimen, yakni rata-rata nilai akurasi pengujian dan waktu komputasi latihan pada sepuluh percobaan untuk menjamin konsistensi hasil pada setiap dataset liver, breast cancer dan heart disease. Untuk membandingkan performa Klasifikasi SVM yang melalui tahap ekstraksi ciri dengan K-Means dan tanpa KMeans, dapat dilihat pada Tabel 1.

Tabel 1. Perbandingan akurasi SVM dengan ekstraksi K-Means dan tanpa ekstraksi K-Means

\begin{tabular}{lcc}
\hline & K-Means \& SVM (\%) & SVM(\%) \\
\hline Liver & 89.87 & 90.60 \\
Breast Cancer & 95.70 & 96.17 \\
Heart Disease & 83.38 & 84.88 \\
\hline
\end{tabular}

Tabel 1 menunjukkan hasil klasifikasi dengan SVM dengan proses ekstraksi ciri terlebih dahulu dengan KMeans dan tanpa ekstraksi ciri. Dari hasil tersebut terlihat bahwa dengan ektraksi ciri K-Means, akurasinya menjadi lebih kecil. Untuk dataset liver, akurasi menurun $0.73 \%$, breast cancer $0.46 \%$, dan heart disease $1.5 \%$. Hal ini menunjukkan hasil yang berbeda dengan penelitian Zheng et.al. (2014) yang menunjukkan peningkatan akurasi.

Tabel 2. Perbandingan waktu komputasi SVM dengan ekstraksi K-Means dan tanpa ekstraksi K-Means

\begin{tabular}{lcc}
\hline & K-Means \& SVM (detik) & SVM (detik) \\
\hline Liver & 0.67 & 1.04 \\
Breast Cancer & 0.33 & 0.68 \\
Heart Disease & 0.38 & 1.20 \\
\hline
\end{tabular}

Dari sisi waktu komputasi saat latihan, hasil eksperimen dapat dilihat pada Tabel 2. Terlihat perbedaan yang cukup signifikan pada penggunaan ekstraksi ciri dengan K-Means, yakni penurunan waktu komputasi. Pada dataset liver, latihan tanpa ekstraksi memerlukan waktu rata-rata 1.04 detik, sedangkan dengan ekstraksi K-Means memerlukan waktu rata-rata 0.67 detik. pada dataset breast cancer, penurunan waktu komputasi mencapai separuh dari waktu awal tanpa ekstraksi ciri, sedang pada dataset heart disease penurunan sangat signifikan dari rata-rata waktu komputasi 1.2 detik menjadi 0.38 detik.

Tabel 3. Penurunan akurasi dan peningkatan komputasi dengan ekstraksi K-Means

\begin{tabular}{lccc}
\hline & $\begin{array}{c}\text { Penurunan } \\
\text { Jumlah Ciri }\end{array}$ & $\begin{array}{c}\text { Selisih Akurasi } \\
(\boldsymbol{\%})\end{array}$ & $\begin{array}{c}\text { Selisih Kecepatan Waktu } \\
\text { Komputasi (detik) }\end{array}$ \\
\hline Liver & $10 \rightarrow 4$ & -0.73 & 0.36 \\
Breast cancer & $30 \rightarrow 5$ & -0.46 & 0.35 \\
Heart disease & $13 \rightarrow 4$ & -1.50 & 0.82 \\
\hline
\end{tabular}

Persentase perubahan akurasi serta waktu komputasi dari eksperimen dapat dilihat pada Tabel 3. Setelah dilakukan ekstraksi dan rekonstruksi yang memanfaatkan K-Means serta fuzzy membership function, penurunan jumlah ciri cukup signifikan, yakni liver sebelumnya memiliki 10 ciri menjadi 4 ciri dengan waktu komputasi saat latihan lebih cepat hingga 0.36 detik disertai penurunan akurasi sebesar $0.73 \%$. Sedangkan pada breast cancer mengalami penurunan jumlah ciri dari 30 menjadi 5 disertai penurunan akurasi sebesar $0.46 \%$ dan peningkatan waktu komputasi lebih cepat 0.35 detik. Penurunan akurasi terbesar pada data heart disease dengan selisih $1.5 \%$, disertai peningkatan kecepatan waktu komputasi sebesar 0.82 detik. Sehingga, proses ekstraksi dan ciri dengan K- 
Means cukup mempengaruhi performa dari klasifikasi, yakni meningkatkan performa komputasi dengan sedikit penurunan akurasi.

\section{KESIMPULAN DAN SARAN}

Pada penelitian ini, dilakukan evaluasi penggunaan algoritma clustering K-Means sebagai ekstraktor ciri pada klasifikasi data liver, breast cancer, dan heart disease dengan SVM. Metode ini mengekstrak ciri berdasarkan pola cluster dari setiap kelas dan merekonstruksi kembali data berdasarkan pola yang telah diekstrak serta menghasilkan ciri abstrak yang akan digunakan dalam latihan untuk mendapatkan klasifikasi.

Penggunaan K-Means sebagai ekstraktor tidak terlalu banyak menurunkan akurasi, tapi signifikan dalam menurunkan waktu komputasi terutama pada data dengan dimensi ciri yang besar, sehingga dapat dipertimbangkan sebagai suatu metode yang mampu meningkatkan performa komputasi terutama klasifikasi dengan SVM.

Semakin hari, data akan semakin meningkat jumlahnya dan semakin banyak sample data, dan dengan perkembangan teknologi akan semakin besar dimensi feature yang diperoleh. Oleh karena itu, metode ekstraksi ciri akan selalu perlu untuk dieksplorasi lebih mendalam untuk mengatasi berbagai masalah yang muncul.

\section{DAFTAR PUSTAKA}

[1] A. Janecek, W. N. W. Gansterer, M. Demel, and G. Ecker, "On the Relationship Between Feature Selection and Classification Accuracy.," Fsdm, vol. 4, pp. 90-105, 2008.

[2] C. Lee and D. Landgrebe, "FEATURE EXTRACTION AND CLASSIFICATION ALGORITHMS FOR HIGH DIMENSIONAL DATA,” 1993.

[3] J. Pohjalainen, O. Räsänen, and S. Kadioglu, "Feature selection methods and their combinations in high-dimensional classification of speaker likability, intelligibility and personality traits," Comput. Speech Lang., vol. 29, no. 1, pp. 145-171, Jan. 2015.

[4] H. Cen, R. Lu, Q. Zhu, and F. Mendoza, "Nondestructive detection of chilling injury in cucumber fruit using hyperspectral imaging with feature selection and supervised classification," Postharvest Biol. Technol., vol. 111, pp. 352-361, Jan. 2016.

[5] A. T. Azar and A. E. Hassanien, "Dimensionality reduction of medical big data using neural-fuzzy classifier,” Soft Comput., vol. 19, no. 4, pp. 1115-1127, Apr. 2015.

[6] Z. M. Hira and D. F. Gillies, "A Review of Feature Selection and Feature Extraction Methods Applied on Microarray Data.," Adv. Bioinformatics, vol. 2015, p. 198363, Jun. 2015.

[7] M. Ahmadi, D. Ulyanov, S. Semenov, M. Trofimov, and G. Giacinto, "Novel Feature Extraction, Selection and Fusion for Effective Malware Family Classification," in Proceedings of the Sixth ACM on Conference on Data and Application Security and Privacy - CODASPY '16, 2016, pp. 183194.

[8] B. Zheng, S. W. Yoon, and S. S. Lam, "Breast cancer diagnosis based on feature extraction using a hybrid of K-means and support vector machine algorithms," Expert Syst. Appl., vol. 41, no. 4, pp. 1476-1482, Mar. 2014.

[9] N. Chamidah and I. Wasito, "Fetal state classification from cardiotocography based on feature extraction using hybrid K-Means and support vector machine," in 2015 International Conference on Advanced Computer Science and Information Systems (ICACSIS), 2015, pp. 37-41.

[10] D. H. Wolpert and W. G. Macready, "No free lunch theorems for optimization," IEEE Trans. Evol. Comput., vol. 1, no. 1, pp. 67-82, Apr. 1997.

[11] D. Dheeru and E. K. Taniskidou, "UCI machine learning repository," University of California, Irvine, School of Information and Computer Sciences, 2017. .

[12] N. Chamidah, Wiharto, and U. Salamah, "Pengaruh Normalisasi Data pada Jaringan Syaraf Tiruan Backpropagasi Gradient Descent Adaptive Gain (BPGDAG) untuk Klasifikasi," ITSMART J. Teknol. dan Inf., vol. 1, no. 1, pp. 28-33, Sep. 2012.

[13] S. Lukasik, P. A. Kowalski, M. Charytanowicz, and P. Kulczycki, "Clustering using flower pollination algorithm and Calinski-Harabasz index," 2016 IEEE Congr. Evol. Comput. CEC 2016, no. 1, pp. 2724-2728, 2016. 
[14] B. Halpin, Halpin, and Brendan, "CALINSKI: Stata module to compute Calinski-Harabasz cluster stopping index from distance matrix,” Jun. 2016.

[15] T. Caliñski and J. Harabasz, “A Dendrite Method Foe Cluster Analysis,” Commun. Stat., vol. 3, no. 1, pp. 1-27, 1974. 